\title{
Štyri rozhovory so štyrmi skladatel'mi zo štyroch krajín Európy [môj i-Portunus]
}

\section{Ondrej Veselý}

V období medzi 5. júlom až 18. augustom 2021 som vd’aka projektu Reconnecting Europe with Guitar ${ }^{1}$ sponzorovanému grantom i-Portunus ${ }^{2}$ precestoval Európu. Cielom mojich ciest bolo navštívit' štyroch skladatelov, s ktorými som priamo na mieste konzultoval kompozície komponované priamo pre tento projekt.

Účastní skladatelia James Helgeson (USA/Berlín), Harri Suilamo (Fínsko), Oliver Kentish (UK/Island) a John E. Zammitpace (Malta) pochádzajú z rôznych umeleckých prostredí, komponujú skladby rozmanitých štýlov a techník, a tým v rámci tohto projektu spolu vytvorili mozaiku možností súčasnej gitarovej hudby.

Ideou projektu bolo opätovné spojenie hudobníkov a skladatelov aktívnych na poli súčasnej hudby, kedže pandémia COVID-19 doslova lokalizovala hudobnú scénu, a tú medzinárodnú takpovediac pripravila o tvorivý kyslík. Online prostredie jednoducho nemôže a nikdy nenahradí živé umenie. Navyše, možnost’ kontinuálne a in medias res konzultovat' so skladatel'mi výsledný tvar ich kompozícií, ktoré pre daný hudobný nástroj píšu, je vzácna a nie tak úplne bežná situácia. Takáto príležitost’ poskytuje skladatel'om šancu overit’ si hratel'nost' komplexnejších štruktúr či modelovat' svoje skladby interpretovi - takpovediac - na mieru a zároveň poskytuje interpretom príležitost’ citlivým spôsobom skladatel’ov navigovat’ v prípade, ak sa vydávajú na „riskantný terén“. Kvalitu a híbku takejto osobnej spolupráce nie je možné dosiahnut’ korešpondenčne. Aj vd'aka tomu bol tento projekt oslavou dočasne obnovenej príležitosti cestovat' a osobne pracovat' so skladatel'mi po celej Európe.

Jamesa Helgesona som po prvýkrát spoznal ako rezidenta festivalu Ostravské dni novej hudby 2019, v rámci ktorého som pôsobil ako hudobný recenzent a publicista pre časopis Hudobný život. Z nášho krátkeho stretnutia prekvapivo vyplynula možnost’ tvorivej spolupráce, kedže gitara pre Jamesa predstavovala silný inšpiračný zdroj a zároveň „vábivú“ kompozičnú výzvu. Dnes je ovocím tohto krátkeho stretnutia nielen naše umelecké a osobné priatel'stvo, ale aj kompozícia August Music, na ktorej finalizácii sme v rámci projektu Reconnecting Europe with Guitar v Berlíne spolupracovali. 
Po návšteve Nemecka putovali moje kroky do fínskeho mesta Salo, kde som strávil 8 dní s miestnym skladatelom Harrim Suilamom. Suilamo komponuje prevažne mikrotonálnu gitarovú hudbu, pričom používa vlastné a zvlášt osobité ladenie strún. Suilamova hudba je koncízna a vo výsledku disponuje precízne cizelovaným kompozičným tvarom. Využívajúc analógiu s médiom textu by som Suilama prirovnal skôr k básnikovi, a nie k rozprávačovi príbehov. Môj prvý kontakt s Harrim Suilamom sa udial pri príležitosti prednášat’ o osobnosti a hudbe Vladimíra Godára na Helsinskej univerzite v marci 2020 na pozvanie svetovo uznávaného semiotika Eera Tarastiho. Ako gitaristu, ktorý sa venuje súčasnej hudbe, ma Tarasti zároveň požiadal o uvedenie Suilamovej skladby Biographie des Schmerzes v rámci osláv 30. výročia založenia Hudobnej spoločnosti Helsinskej univerzity, ktoré sa udiali deň po spomínanej prednáške. Zvláštna prítažlivost' a jedinečnost' Suilamovej hudby ma vtedy upútala natol'ko, že som sa o rok nato rozhodol pozvat' ho do môjho projektu, v rámci ktorého skomponoval skladbu Wilde's Comma.

Vol'ba zapojit' do projektu britského skladatel'a desat'ročia žijúceho na Islande (a s islandským občianstvom) Olivera Kentisha, ako aj Johna E. Zammitpaceho z Malty súvisela predovšetkým s mojou zvedavostou a chutou vydávat' sa na neprebádané umelecké cesty. Malta prestavuje v mojom (po)vedomí krajinu typickú predovšetkým turizmom a diskotékovou kultúrou. Z týchto dôvodov bola pre mňa idea spolupracovat' s maltským skladatel'om taká pútavá - periférna kultúra ma vždy umelecky značne pritahovala. Zammitpace sa nakoniec tiež rozhodol - a to bez mojej intervencie - pristúpit' k tomuto projektu z kultúrneho hladiska: venoval mi kompozíciu, ktorú nazval Slovalta, kombinujúc názvy našich krajín. Rovnakým spôsobom vznikla spolupráca s Oliverom Kentishom, ktorý je pre gitaru azda najviac píšucim islandským skladatelom. Islandskú hudbu vnímam ako akýsi endemit európskej kultúry. Je nám blízko i d’aleko. Zároveň je v nej cítit’ prírodu takým spôsobom, aký by v súčasnej slovenskej kompozícii vzbudzoval azda vel'ké rozpaky. Kentish pre môj projekt skomponoval skladbu Thoughts in a Pandemic II, a teda dielo reagujúce na súčasnú pandémiu COVID-19.

Tak či onak, projekt Reconnecting Europe with Guitar spojil môj vzt’ah k súčasnej hudbe s radostou zo spoločnej práce so skladatel'mi a v neposlednom rade i s láskou k cestovaniu a rozličným kultúram. Predkladané rozhovory sú vedlajším „ovocím” projektu. 
James Helgeson

Berlín, Nemecko, 10. júl 2021

O. V.: James, prezrad' niečo o genéze svojho vztahu k hudbe, o detstve a vyrastaní v Spojených štátoch amerických!

J. H.: Vyrastal som v univerzitnom meste v USA, ned’aleko Chicaga a svojím spôsobom som mal vel'ké št’astie, ked'že sa tam uvádzalo vel’a dobrej hudby. Spieval som v zbore, čo malo na mňa obrovský vplyv. Ako devätročný som mal možnost' spievat’ Mahlerovu Tretiu symfóniu či Brittenovo Vojnové rekviem, čo bola skúsenost', ktorá formovala môj záujem o kompozíciu.

Mal som tiež št’astie v tom, že moji rodičia boli akademici. Vel’a sme cestovali, a tak som ako tínedžer strávil vel’a času v zahraničí, predovšetkým v Paríži. Neskôr som šiel študovat' na Curtisov hudobný inštitút vo Filadelfii, ako aj na Oberlin College a na Konzervatórium v Ohiu. Na Princetone som neskôr získal doktorát z renesančnej literatúry; vd'aka tomu som sa opät' dostal aj do Paríža.

O. V.: Zaujímavá je tiež tvoja profesionálna „dvojdomost”. Po dvoch dekádach prednášania renesančnej literatúry na svetovo najuznávanejších univerzitách si sa vrátil ku komponovaniu súčasnej hudby. Poskytuje ti tvoja odborná skúsenost’ s literatúrou inú perspektívu v pohlade na hudbu?

J. H.: Povedal by som, že nie som ten pravý, kto by mal posúdit', či má literatúra vplyv na moju hudbu. Zaiste, myslím si a aj dúfam, že tam vplyv je. Sú veci, ktoré ma zaujímajú hlavne vd’aka mojej skúsenosti s literatúrou, respektíve sú veci, ktoré by mi azda neprišli len tak na um, keby som mal za sebou výlučne tradičné hudobné vzdelanie. Konkrétne mám na mysli kombináciu hudby a poézie, najmä v neskorostredovekej a ranorenesančnej hudbe, ktorá je pre mňa velmi dôležitá, a to v oboch oblastiach mojej kariéry. Mat’ celkom odlišnú perspektívu vychádzajúcu z dvoch rozdielnych oblastí umeleckej činnosti nemôže byt' na škodu. Navyše, úplne nezvyčajné to nie je. Spomeniem napríklad amerického skladatel'a Christiana Wolffa, ktorý bol dlhodobo profesorom klasickej literatúry, a myslím si, že aj Elliott Carter učil, niekedy počas svojej kariéry, starogréčtinu. Umelecká cesta takpovediac oklukou je cestou, ako sa dopracovat' k zaujímavým umeleckým výsledkom. Teda aspoň dúfam... Prirodzene, existujú aj takí skladatelia, ktorí sa vydali úplne priamou cestou. Avšak onú spomínanú „okluku“ považujem za plodnú a užitočnú.

O. V.:V týchto kontextoch ma zaujíma tvoj postoj voči názorom tvrdiacim, že hudba a jazyk sú postavené na tých istých základoch.

J. H.: Tvrdenie, s ktorým sa často stretávame, a to, že hudba je jazyk, či dokonca univerzálny jazyk, mi bolo vždy podozrivé. Zaiste, v hudbe existujú také veci, ktoré možno opísat’ z lingvistickej, či dokonca sémantickej stránky. Som však presvedčený, že hudba je médium, ktoré sa v mnohých a dôležitejších ohladoch značne od jazyka odlišuje.

Ku koncu môjho pracovného pobytu vo Vel'kej Británii - kde som učil na univerzite v Cambridge a neskôr aj v Nottinghame - som bol súčastou istého projektu v Oxforde sponzorovaného Balzanovou nadáciou. Skúmali sme vztah literatúry a kognície. 
Zaujímavostou projektu bola účast' Deirdre Wilsonovej, lingvistky z University College London, ktorá je vel'mi známa tým, že spolu s Danom Sperberom rozvíja teóriu tzv. lingvistického významu. Vd’aka tomuto projektu som sa chcel zaoberat' otázkou, ako by bolo možné teóriu jazykovej relevancie použit’ v súvislosti s uvažovaním o očakávaniach v hudbe. Kedž̌e to bol pomerne krátkodobý projekt, nepodarilo sa mi do toho naplno pustit'. Predpokladám však, že tému očakávania a jeho významu pre definovanie čohosi ako hudobný význam nakoniec preskúmam.

\section{O. V.: A čo komunikácia a hudba?}

J. H.: Komunikácia je azda i nesprávne slovo. Podla môjho názoru hudba prináša možnost', ako byt’ spolu. Vytvára efemérne, krátkodobé komunity medzi poslucháčmi, skladatel'mi, interpretmi a publikom. Komunikácia - v určitom zmysle - implikuje sémantický obsah, okrem d'alších vecí... Je pre mňa t’ažké pochopit', čo by tento obsah v hudbe mohol byt'. Hudba však určite prináša spôsob, ako spojit’ ludí a umožnit’ im spoločné prežívanie určitého druhu estetického zážitku.

O. V.: Predpokladám, že návrat ku komponovaniu hudby po štyridsiatke prináša určitú rezistenciu voči trendom, resp. poskytuje istý vyzretý a sústredený postoj k tvorbe. Moja nasledujúca otázka z tejto premisy vychádza, a teda: ako vnímaš vzt’ah medzi tradíciou a možnost’ami pokroku v súvislosti so súčasnými trendmi a vývojom v súčasnej hudbe?

J. H.: Už nemám dvadsat’ rokov, čo je aj výhodou, aj nevýhodou. Niekedy by som chcel mat’ opät' dvadsat', ale máš pravdu v tom, že vd'aka svojmu veku som už do istej miery obozretný voči trendom. Aj ako profesora literatúry ma vždy fascinovali l'udia, ktorí prichádzajú takpovediac „zvonka“. Ako napríklad Beckett, ktorý nebol Francúz, ale písal po francúzsky. Podlia mňa bol môj návrat ku kompozícii, po onej dlhej odmlke, čosi ako príchod do tak trochu cudzej krajiny. Myslím si aj, že trendy neberiem už ako samozrejmost', respektíve, že im nepodlahnem tak rýchlo, ako ked'som mal dvadsat', čo je vel'mi užitočná perspektíva.

\section{O. V.: Mala pandémia COVID-19 a izolácia s ňou spojená dopad na tvoju kompozičnú prácu?}

J. H.: Skladatelia sú relatívne samotári, aj ked' ja mám partnera, takže som úplne sám nebol. Pýtaš sa však na obdobie, v ktorom onen druh spojenia či komunikácie, súvisiacej s hudbou, nebol možný. Vela ludí trpelo ako emocionálne, tak aj finančne a mnoho výkonných hudobníkov bolo za posledný rok vo vel'mi vel'kej tiesni.

V prvom lockdowne som napísal vel'ké množstvo hudby. Komponovanie hudby bolo vlastne mojím spôsobom, ako sa vysporiadat’ s izoláciou. V druhom a tretom lockdowne - a predovšetkým v tom dlhom, z ktorého sme sa len nedávno dostali som zistil, že komponovat’ je pre mňa vel'mi tažké. V prvom lockdowne som dopísal sláčikové kvarteto a tiež cyklus kánonov, ktoré som nazval Sedem kánonov pre morovú jar v nádeji, že to bude posledná taká jar. Teraz to ale vyzerá, že COVID bude s nami ešte dlho, ja však už znovu komponujem. 
August music

(for Ondrej Veselý)

I. Notturno. Sognando $\bullet=72$

(5) (6)

rit.
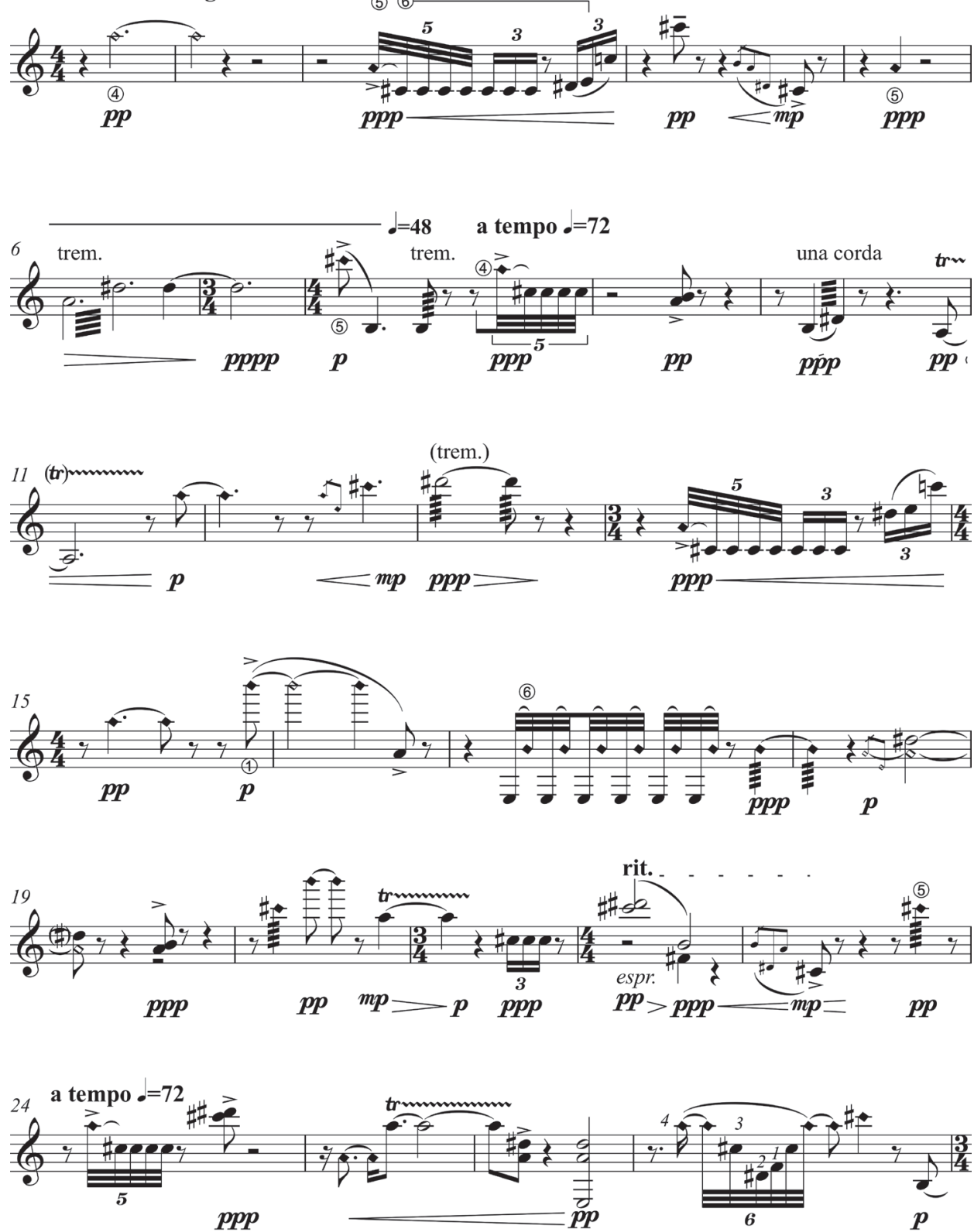

(C) by James Helgeson. All rights reserved. 
O. V.: Je vel’a skladatel'ov, ktorých hudba je do velkej miery spojená s ich časopriestorom. Ich hudba reaguje napríklad na náboženstvo, politiku a podobne. Reaguje i tvoja hudba na obdobné vonkajšie kontexty, alebo komponuješ nezávisle od nich, si skôr skladatel'om autonómnej či reakčnej hudby?

J. H.: Je možné, že slovo „reakčný“ používame v dvoch odlišných významoch... Dúfam, že som autonómny skladatel', nepovažujem sa za reakčného skladatela. Myslím si, že je vel'a reakčnej hudby, ktorá znie nevýrazne. Znie, akoby bola skomponovaná pred sedemdesiatimi rokmi. Dúfam, že moja hudba takou nie je. V žiadnom prípade sa nesnažím byt' revolučným, ani to a priori nepovažujem za nejako zaujímavé, ak sa niekto snaží byt' revolučným. Píšem hudbu, ktorú chcem napísat'. Ak sa niekomu páči, tak je to skvelé. A to ma, predpokladám, robí autonómnym.

James Helgeson je americký skladatel' a hudobný vedec pôsobiaci v Berlíne. Prvý titul získal na Curtis Institute of Music, po ktorom nasledoval bakalársky titul na Oberlin College and Conservatory. V súčasnosti končí doktorát z hudobnej kompozície na Royal Holloway na University of London. Je tiež držitel'om doktorátu z Princetonu, kde študoval renesančné teórie hudby a poézie. Prednášal v Cambridge, Nottinghame a na Columbia University. V súčasnosti pôsobí na pomedzí hudby, literatúry a filozofie a je zakladajúcim členom umeleckého kolektívu AGOSTO (http://jameshelgeson.com).

\section{Harri Suilamo}

Salo, Fínsko, 15. júl 2021

\section{O. V.: Harri, prezrad'niečo o svojom detstve, štúdiách, ako aj o genéze svojho záujmu o hudobnú kompozíciu!}

H. S.: Moje zázemie je trochu neobvyklé v tom, že pochádzam z úplne obyčajnej, robotníckej rodiny a z mesta, kde v časoch môjho detstva nebola ani hudobná škola. Môj prvý kontakt s hudbou priniesla ústna harmonika, ktorú som dostal od deda, a gramofón, ktorý zostrojil môj otec - stolár. Na ňom som si v detstve prehrával vtedajšie "hlinené" dosky na rýchlosti 78 otáčok za minútu. ${ }^{3}$ Raz sa v podkroví domu nášho príbuzného našla zlomená mandolína, ktorú môj šikovný otec pre mňa okamžite opravil. Tak sa začali moje autodidaktické štúdiá, na strunových nástrojoch... V d’alšej fáze som sa, po vzore rockových kapiel, naučil hrat' na elektrickej gitare a tiež čítat’ a písat' noty.

V 70. rokoch sa v rockovej hudbe objavil nový štýl - progresívny rock, ktorý uprednostňoval komplexnejšie rytmické a harmonické štruktúry. K duchu vtedajšej doby patrilo aj to, že hoc sme sa pohybovali výlučne na poli populárnej hudby, počúvali sme popritom i množstvo klasickej, koncertnej hudby. Približne v rovnakom čase som začal študovat’ aj hru na klasickej gitare a hudobnú teóriu na novozaloženej hudobnej škole v našom meste. Zároveň som hral na elektrickej gitare a písal piesne. Mali sme rockovú kapelu Nimbus, s ktorou sme v roku 1974 vydali LP platňu s názvom OBUS. V tomto období som zvykol zapisovat’ všetky rockové skladby do partitúr, z ktorých stále ešte niektoré mám. Od toho všetkého bol potom už len krôčik k čisto umeleckej hudbe. V čase vydania spomínaného hudobného albumu som začal študovat’ hudobnú vedu na vysokej škole a ako vedlajšie predmety som si vybral teoretickú filozofiu a kultúrne 
dejiny. Toto všetko, spolu s odchodom z môjho rodného mesta, znamenalo odtrhnutie sa od rocku a populárnej hudby. Tak som po ukončení vysokoškolského štúdia v odbore hudobná veda odišiel do Helsínk študovat' hudobnú kompozíciu pod vedením Paava Heininena na Sibeliovej akadémii.

\section{O. V.: Aké bolo štúdium pod jeho vedením a ako si spomínaš na jeho vyučovacie metódy?}

H. S.: V tom čase bol Paavo Heininen, spolu s Einojuhanim Rautavaarom, najdôležitejším učitel'om kompozície vo Fínsku. Ako skladatel' predstavoval Heininen tradíciu atonálnej moderny, a preto som ho ako študent vedome vyhladal. Napriek tomu boli jeho vyučovacie metódy a pedagogický prístup nesmierne klasické, zamerané na tradíciu. Napríklad, celý prvý ročník spočíval predovšetkým v osvojovaní si základných harmonických, a hlavne kontrapunktických zručností. Hudobné „remeslo“ by preto mohlo byt' klúčovým mottom Heininenovej kompozičnej pedagogiky.

Ďalším charakteristickým znakom jeho výučby bola značná multidisciplinárnost'. Jeho hodiny sčasti zahŕňali híbavé diskusie o literatúre a výtvarnom umení. Nebolo tiež neobvyklé, že niektoré kompozičné úlohy a cvičenia siahali svojím charakterom k výtvarnému umeniu. Aj Heininenove znalosti repertoáru boli ohromujúce. Dodnes som vd’ačný za to množstvo jeho odporúčaní ohladom menej známych, viac periférnych skladatel'ov, ktorých umenie poznal a rozpoznával v ňom nepopieratel'nú hodnotu.

\section{O. V.: Ktorí skladatelia a kompozičné školy mali na tvoju hudbu najväčší vplyv?}

H. S.: Heininen bol v 70. a 80. rokoch vo Fínsku takým dominantným skladatelom a pedagógom, že sa doslova hovorilo o Heininenovej škole. V dobrom aj v zlom... Prirodzene, kedže som pod jeho vedením študoval niekolko rokov, tak uznávam, že patrím do tejto skupiny. To však neznamená akýsi štylistický alebo estetický konformizmus v zmysle nejakej skladatel'skej školy. I skladatelia druhej viedenskej školy Schoenberg, Berg a Webern vždy trvali na tom, že nie sú subverzívni, ale že nadväzujú na tradíciu. A na ich tradíciu potom nadviazali majstri narodení v 20. rokoch 20. storočia, ako napríklad Berio, Boulez, Ligeti, Nono a Stockhausen. Každý svojím osobitným spôsobom... Rád by som ale spomenul troch skladatelov, ktorí sú pre mňa osobitne dôležití, a to Bernd Alois Zimmermann, Salvatore Sciarrino, a najmä Klaus Huber, ktorého jemná hudba a hlboký humanizmus na mňa velmi zapôsobili. To je ono širšie jadro hudobných kontextov, v ktorých som mohol žit a pracovat'. Treba ale spomenút aj mojich rovesníkov a celý zvyšok kultúry... Všetko na všetko vplýva, takým či onakým spôsobom.

O. V.: Tvoja hudba sa vyznačuje, okrem iného, koherentnými formami, inovatívnym prístupom k zvukovým možnostiam nástrojov, ako aj celkovým zameraním na auditívne vyznenie skladieb. Môžem sa opýtat', čo stojí na začiatku tvojich kompozícií a na čom ti naviac záleží počas rozvíjania hudobného materiálu?

H. S.: Fínsky skladatel' Jukka Tiensuu povedal, že každá skladba musí mat' svoj vlastný, osobitný dôvod vzniku a ja nemôžem nič iné, len súhlasit.... Všetko sa začína od počiatočných podmienok a predpokladov stanovených v zárodkoch tvorivého aktu. Môžem 
sa však pokúsit’ charakterizovat’ niektoré všeobecné črty svojich pracovných metód. Zaujímam sa o timbre, farbu, ktorá je prirodzene určená hudobnými nástrojmi, pre ktoré v danom okamihu píšem. V niektorých svojich dielach som siahol aj k neobvyklejším nástrojom, ako napríklad v koncertnej skladbe pre fínsky l'udový nástroj - kantele. Mám tiež dielo pre 25-strunové japonské koto. Ďalšiu skladbu som skomponoval pre historické, dobové nástroje. Niektoré moje orchestrálne diela som zas takpovediac „okorenil“ akordeónom, elektrickou gitarou či barytónovým saxofónom a podobne. Ked’komponujem pre určitý hudobný nástroj, snažím sa zadovážit' si ho. Následne ho študujem, podrobnejšie skúmam a pomocou zvukových experimentov hladám možné inovácie.

Vo svojej hudbe sa vo všeobecnosti hlásim k tonálnemu a harmonickému jazyku, aj ked'vo svojich dielach využívam aj takzvané nekonvenčné, rozšírené nástrojové techniky. Z tohto hladiska je moja hudba dost’ tradičná - dôležitým pre mňa je zakaždým to, ako hudba „znie“. Musí byt’ zvukovo zaujímavá a musí byt’ výsledkom vedomej tvorivej práce. Preto ako skladatel' nevyužívam princíp náhodnosti a ani improvizáciu, hoci mám tieto princípy rád, ked'improvizujem či počúvam džezový koncert. Programové, ako aj mimohudobné rozmery sa v mojej hudbe rovnako dostali do úzadia. Objavujú sa výlučne v názvoch mojich diel a siahajú napríklad do sveta vizuálneho umenia alebo literatúry. Používam ich však len na to, aby som svojim dielam dodal akúsi kultúrnu „auru“. Čo sa týka hudobnej formy, musím povedat’, že nemám vo zvyku vopred plánovat' formovú štruktúru skladieb. Ich forma vzniká organicky, resp. sa definuje sama v priebehu komponovania.

Dodnes zvyknem písat' svoje partitúry ručne a ceruzkou... Čiastočne kvôli môjmu záujmu o kaligrafiu. Toto svojrázne, každému skladatel’ovi osobité notografické remeslo dokáže v niektorých výnimočných prípadoch pozdvihnút’ notovú partitúru na úroveň výtvarného umenia. Na druhej strane mi písanie rukou umožňuje tiež nasledovat’ akúsi estetiku pomalosti, na rozdiel od ideálov rýchlosti a efektnosti, či až povrchné paste/copy hudobné myslenie.

\section{O. V.: Okrem iného si aj jedným z najplodnejších skladatel’ov fínskej gitarovej hudby, v ktorej už niekol'ko rokov výhradne využívaš mikrotonálnu organizáciu oktávy. Môžeš o svojej fascinácii mikrotonálnou hudbou povedat' viac... ako aj o tom, prečo je práve gitara najvýraznejším nositel'om tejto časti tvojej tvorby?}

H. S.: Vo svojich posledných gitarových skladbách som sa rozhodol využívat' mikrotonalitu, pretože tak môžem rozšírit', či skôr skomprimovat' rozsah tónového priestoru, ktorý mám k dispozícii. Mikrotonalita vznikne, ked’sa zaužívaný poltón medzi susednými klávesmi na klavíri ešte viac zmenší, na dve menšie polovice - tak vznikne štvrttón. Alebo ked'sa celý tón rozdelí na tri časti... Svoju vlastnú mikrotonalitu som ale neimplementoval do svojej tvorby komponovaním pre nové hudobné nástroje, špeciálne zostrojené pre mikrotonálnu hudbu. Vytvoril som si totiž vlastné mikrotonálne ladenie, a to na tradičnej gitare. Vo svojej úplne poslednej gitarovej skladbe Die Trauben hängen saftig - Bernhard Fragmente // z roku 2020 som zašiel ešte d’alej - z gitary som odstránil všetky struny, ponechal som na nej len tie najhrubšie. Gitara má stále 6 strún, ale všetky sú hrubé, nízko znejúce. Tieto struny som potom mikrotonálne naladil, a to v pomerne úzkom rozsahu. Následne som experimentoval, alebo lepšie povedané hral sa. Vydal som sa na hudobne objavitel'skú cestu do sveta možností, ktoré som si práve vytvoril... 
Harri Suilamo

\section{Wilde's comma}

kitaralle / for guitar / für Gitarre

(2021)

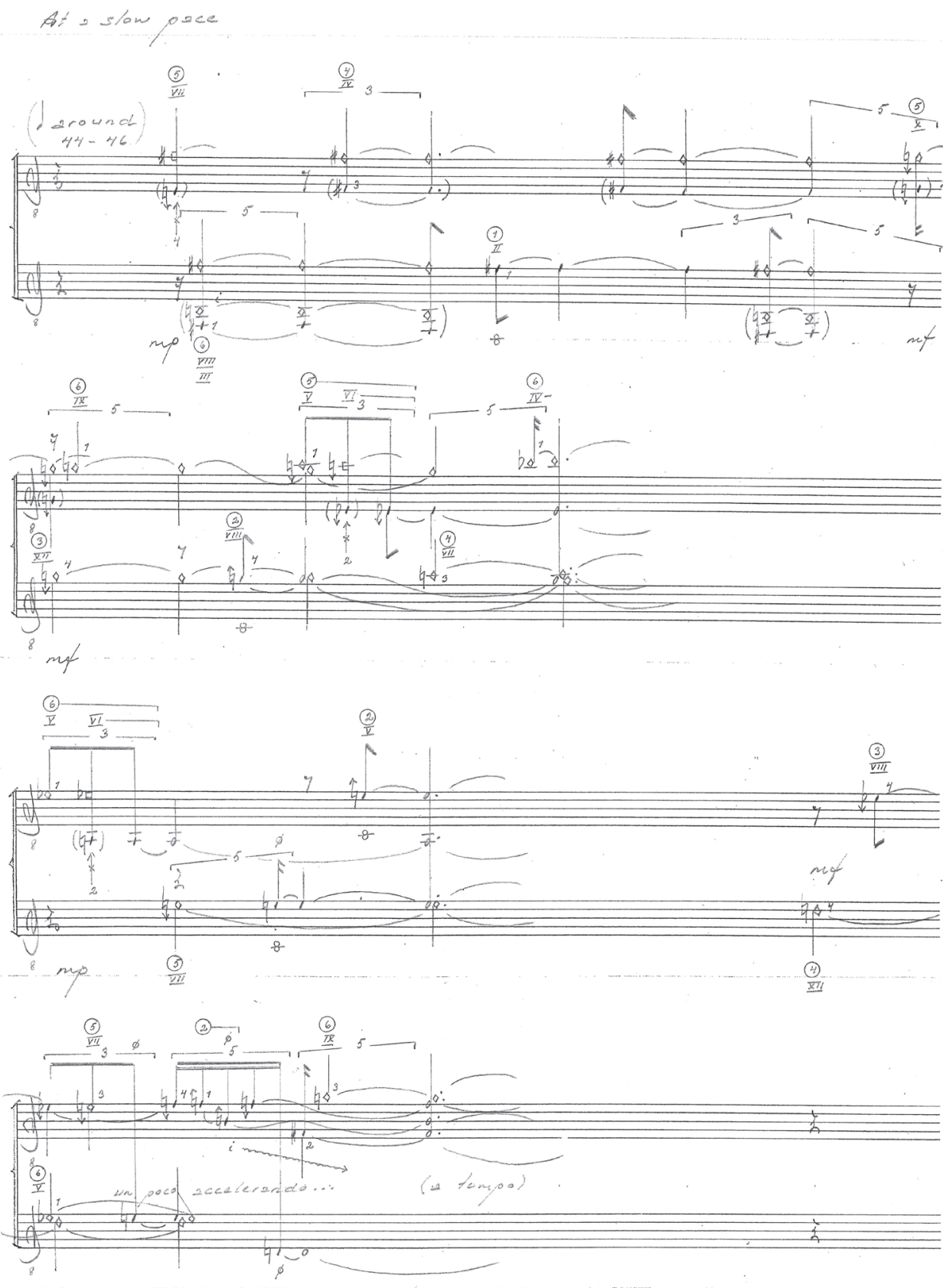


O. V.: Mala pandémia COVID-19 a izolácia spojená so stratou l'udského kontaktu nejaký vplyv na tvoju hudbu? Nepýtam sa iba na praktické veci spojené s komponovaním, ale túto otázku smerujem aj k estetickým a štylistickým aspektom tvorby.

H. S.: V konečnom dôsledku mala táto pandémia COVID-19 na moje aktivity relatívne malý dopad. Hrozby a izolácia spojené s pandémiou určite zapríčinili u mňa ak nie depresiu, tak aspoň určitú melanchóliu v tvorivom myslení a každodennom živote. Chýbajú mi tiež kolegiálne kontakty a stretnutia, ktoré sa, dúfam, čo najskôr stanú opät’ súčastou bežného života. Musím ale povedat', že vel'mi súcitím s výkonnými umelcami. Sú to oni, ktorí stratili kvôli Covidu množstvo pracovných príležitostí, kedže sa koncertný život znížil na minimum s ciel’om zabránit' šíreniu pandémie. Posledné obdobie znamenalo pre nich vel'ké finančné t’ažkosti.

\section{O. V.: Moja posledná otázka je prozaická. Na čom v súčasnosti pracuješ a aké sú tvoje kompozičné plány do budúcnosti?}

H. S.: Momentálne dokončujem sedemdielny cyklus madrigalov na texty fínskeho básnika Harriho Nordella. Ide o šest'hlasné dielo pre vokálny súbor s volitel’ným nástrojovým zdvojením. Fínsky akordeonista Mikko Luoma ma požiadal tiež o novú sólovú skladbu pre svoj nástroj. Táto kompozícia je však ešte stále vo fáze brainstormingu. Život teda pokračuje ako predtým, pomaly, ale isto, malými krokmi...

Hudba Harriho Suilama sa pohybuje v priestore hudobného modernizmu s príchutou post-serializmu a mikrointervalov. Suilamo uprednostňuje značne stručné formy a jeho tvorba pozostáva takmer výlučne z komornej hudby. Neuspokojuje sa s konvenčnými súbormi, ale neustále hladá nové kombinácie ako napríklad akordeón a fínske kantele (https://core.musicfinland.fi/ composers/harri-suilamo).

\section{Oliver Kentish}

Reykjavik, Island, 6. august 2021

O. V.: Oliver, prezrad'niečo o svojom detstve a o tom, aké bolo vyrastat' v Spojenom král'ovstve? Aké boli tvoje prvé kontakty s hudbou?

O. K.: Moje hudobné začiatky boli, myslím si, úplne všedné. Začal som spievat’ v cirkevnom zbore, ešte ked' som spieval chlapčenským sopránom. Ked' som mal približne 12 rokov, opýtal sa nás učitel' hudby na základnej škole, či sa chce niekto z nás učit' hrat na violončele. Vtedy som vlastne ešte ani nevedel, čo to violončelo je, ale môj najlepší kamarát zdvihol ruku, tak som ju zdvihol aj ja. A tým, niekto by to nazval „nehodou“, sa začala moja kariéra violončelistu. Popritom som sa učil tiež hrat' na hoboji. Môj učitel' bol ale taký zaneprázdnený úpravou hobojových plátkov a koncertovaním, že som mal len vel'mi málo hodín. Sústredil som sa teda na violončelo. Neskôr, ked'som mal asi 15 rokov, som navštevoval Centrum pre mladých hudobníkov, ktoré viedla vtedajšia londýnska krajská rada. Musel som urobit konkurz, a následne som navštevoval sobotné intenzívne hudobné tréningy. Strávil som tam celé dni na hodinách violončela, 
hudobnej teórie, klavíra a orchestra. V tom období som tiež hral v tzv. London Schools Symphony Orchestra, ktorý funguje dodnes. Ide o orchester zložený zo študentov z celého Londýna, a to doslova zo všetkých miestnych škôl. S týmto orchestrom som hral, až kým som - približne v mojich 19 rokoch - neabsolvoval strednú školu. Potom som už pokračoval na Královskej akadémii hudby. Takéto boli moje hudobné začiatky v skratke.

\section{O. V.: Čo stálo za rozhodnutím prest’ahovat’ sa, žit’ a pracovat’ na Islande? Aký je za tým príbeh?}

O. K.: V jednom z orchestrov, v ktorých som hral, bol istý dirigent, ktorý bol známy ako vel'ký vtipkár. Bol i mojím kamarátom a raz mi zavolal so slovami: „,Ako by sa ti páčilo pracovat'na Islande?" Povedal som mu, aby si zo mňa nerobil posmešky, a že mám skúšku s kvartetom. Položil som mu teda telefón so slovami, aby ma nerušil. Nasledujúci deň mi zavolal znovu: „Oliver, myslím to vážne. Hladajú violončelistu do Islandského symfonického orchestra. Zajtra! Zapísal som ta, musís sa konkurzu zúčastnit' !" Nakoniec som teda na konkurz šiel a tu prácu som dostal.

O. V.: Pochopitel'ne, od tvojho prestahovania sa na Island ubehli už desat'ročia. Vedel by si však ešte stále poukázat' na kultúrne rozdiely medzi Spojeným královstvom a Islandom v súvislosti s hudbou?

O. K.: Myslím si, že hlavným rozdielom medzi Islandom a Vel'kou Britániou je to množstvo amatérskeho muzicírovania. Na Islande je to celkom vzácny jav, zato v Británii je zas značne rozšírený, každá mestská čast’ má vlastný orchester či ansámbel. Len v Londýne existujú stovky amatérskych orchestrov, ale na Islande je iba jeden. Založený bol pred 30 rokmi a dnes ho vediem ja. Zaujímavé je však i to, že slovo amatér na Islande neznamená nič dobré. V skutočnosti ho ludia nemajú vel'mi radi a nechcú, respektíve najmä v minulosti nechceli byt' s tým slovom spájaní. Verím však, že sme sa v tomto ohlade už dost' pohli vpred. Náš orchester koncertuje na dobrej úrovni, naše koncerty sú vypredané a hrajú s nami tí najlepší islandskí sólisti. Tieto postoje pomáha menit’ aj islandské hudobné školstvo.

O. V.: Pravdepodobne teraz položím nezodpovedatel'nú otázku. Avšak... vd’aka čomu je islandská hudba taká unikátna v kontexte európskej vážnej, resp. súčasnej hudby?

O. K.: V skutočnosti je to vel’mi jednoduchá otázka. Islandská hudba je totiž vel'mi, vel'mi mladá! Možno by bol dobrý nápad porozprávat trochu o jej histórii... Predstav si, že si uviazol na ostrove niekde uprostred severného Atlantiku. Je tam zlé počasie, nemáš žiadne lode, neustále sneží a sopečné erupcie sú na každom kroku... Zároveň si sa v 14. a 15. storočí ocitol pod útlakom severonemeckých hanzovných obchodníkov a neskôr si 200 rokov pod útlakom Dánska. Jediné, o čo sa teda Island’ania mohli usilovat', bolo prežitie. O hudbu sa vel'mi nezaujímali. Nepovažovali ju za niečo, čo by bolo dobré pre dušu a zároveň nebola ani užitočná. Island’ania museli vel'mi tvrdo pracovat'...

Naším prvým vzdelaným skladatel'om bol Sveinbjörn Sveinbjörnsson, ktorý, okrem iného, skomponoval aj našu národnú hymnu. Ide o koniec 19. a začiatok 20. storočia. 
Do tej doby tu neexistovalo vôbec žiadne muzicírovanie! Cirkev, samozrejme, mala svoje rímskokatolícke spevy a obrady a bolo tu tiež zopár ludí, ktorí ich zbierali. V poslednom období sa de facto objavuje čoraz viac stredovekej cirkevnej hudby z Islandu. Inak tu však domáca hudobná tvorba neexistovala. Žiadne hudobné nástroje, iba l'udský hlas... V tomto prostredí sa vyvinula tzv. „kvintová pieseň“, ktorá je typicky islandská. Spievajú ju dva hlasy v paralelných kvintách, ktoré sa potom prehodia, takže horný hlas ide do basu a spodný hlas nahor. Takýto je tradičný islandský spev, ktorý pochádza ešte zo starých čias, ked' ludia sedávali počas dlhých chladných nocí vo svojich trávnikových domoch okolo ohňa.

Koncom 19. storočia priniesol Pétur Guðjohnsen na Island prvý chrámový organ. Bol to praprapradedo mojej ženy. Guðjohnsen bol prvý hudobník, ktorý sa usadil na Islande a učil tu hudbu. Až odvtedy sa tu začala vyučovat’ hudba. Ako hovorím, hudba mala na Islande neskorý štart, odvtedy sa však šíri doslova explozívne.

Podla mňa bol prvým vel'kým islandským skladatel'om medzinárodnej úrovne Jón Leifs, vd’aka ktorému bolo odrazu možné Island považovat’ za miesto, kde existuje trochu civilizácie. Jeho hudba je velmi náročná, ale aj mimoriadne jedinečná a nadväzuje na spomínanú tradíciu kvínt. Zároveň o islandskej hudbe nemožno hovorit’ bez toho, aby sme spomenuli aj islandskú prírodu. Všetky tie skaly, náročná krajina... Ak myslíte na Sibelia a Fínsko, alebo na Griega a Nórsko, tak obdobne myslíte na Jóna Leifsa a Island - jeho status je obdobný. Jeho hudba odráža túto krajinu, ako aj temperament islandského skladatela. Island’an sa nevzdáva, lebo nemôže. Ak sa vzdáš, tak neprežiješ - to charakterizuje život tunajších rybárov a farmárov. A presne toto charakterizuje aj Jón Leifs - jeho hudba je náročná, ale „stojí ako kus skaly“. Jeho vplyv je tu stále cítit', aj ked'sa poslednú dobu trochu oslabuje, kedže vela súčasných islandských skladatelov študovalo v zahraničí. Vždy je však s nami naša história, aj v celej islandskej hudbe. Aj v hudbe Björk je počut' niečo jedinečné a iné, hoc, možno je to tým, že veríme na škriatkov a trollov.

\section{O. V.: Myslíš, že aj Björk verí na elfov a trollov?}

O. K.: Absolútne, všetci v nich veria!

\section{O. V.: Sú nebezpeční?}

O. K.: Nie, sú zlomysel'ní, nie nebezpeční.

\section{O. V.: Ako by si definoval pozíciu súčasnej artificiálnej hudby na Islande?}

O. K.: Nebyt' COVID-u, dialo by sa tu vel’a rozmanitých podujatí. Poviem ti príklad. Ked' som sem v roku 1977 prišiel, symfonický orchester odohral jeden koncert za dva týždne. Ďalší týždeň sme iba nahrávali pre rozhlas, a to bola azda jediná hudba, ktorá sa tu hrala. V Reykjavíku bol i hudobný klub, v ktorom bol jeden koncert za celú zimu! V lete si chcel každý užit’ dobré počasie, alebo pracoval na poli. Takto to tu bolo ešte v roku 1977, ked' som sa sem prest’ahoval. Dnes sa v Reykjavíku odohrá približne 12 až 15 koncertov každý deň. Stále sa tu niečo deje. Vd'aka malej komunite l'udí, ktorou Island je, má každý šancu. Každý jeden môže vyjst’ na pódium. Každý má priatelov, 
príbuzných, ludí, s ktorými učí alebo hrá v orchestri. Všetci títo ludia prídu a podporia ho. Malá komunita je úžasná vec a vyplýva z nej vel’a dobrého. Každý rok sa tu odohráva festival nazývaný Iceland Airwaves. Ide o rokový festival, na ktorý prídu každý november ludia z celého sveta. Ďalej tu máme Islandský symfonický orchester, ktorý dnes koncertuje niekol'kokrát za týždeň. Či už v koncertnej sieni, alebo na školách, v nemocniciach po celej krajine alebo v zahraničí. Za posledných 20 až 30 rokov sa teda udialo vela. Je to tu taký úžasný vriaci kotol všetkej hudby.

$\mathrm{Na}$ Island’anoch je tiež niečo, čo by si azda nečakal - sú vel'mi tolerantní. Dajú ti šancu a prídu si t’a vypočut'. Ked' som sem v 70. rokoch prišiel, vnímal som túto spoločnost' ako vel'mi introvertnú. Bolo t’ažké sa s niekým zoznámit'. Tých prvých pár rokov som prežil viac-menej sám. Postupne sa však spoločnost' otvárala, a to predovšetkým v súvislosti s tým, že čoraz viac l'udí odchádzalo a prichádzalo zo zahraničia. Dnes sú Island’ania už neuveritel'ne tolerantní, milí a vedia byt' nápomocní. A to je skvelé! Každý druhý Island’an je tiež básnik alebo maliar, alebo hrá na nástroji. Preto sa tu toho v umení deje tak vela. Napríklad, typickým vianočným darčekom je u nás kniha. Ĺudia tu vel'a píšu a knižný trh na Vianoce prekvitá. Ĺudia vel'a čítali a čítajú, predovšetkým však tradičné ságy z 13. storočia. Knihy sú pre nás dôležité, a to platí aj pre poéziu. A k tomu všetkému sa dnes pripojila i hudba, ktorá sa stala mimoriadne dôležitou súčastou islandskej kultúry.

\section{O. V.: Presuňme sa k finančnej pomoci zo strany Islandského štátu - aké tu existujú grantové schémy pre hudobníkov a skladatelov?}

O. K.: Na túto otázku je mi dost' tažko odpovedat', ked’že som to neskúmal, ale môžem povedat', že Islandský štát vo všeobecnosti vel'mi nepodporuje umenie. Máme tu granty, ako aj súkromné firmy podporujúce umenie, ale podpora umenia by mohla byt’ lepšia. Je tu jeden grant, o ktorý môžeš požiadat' bud' islandský rozhlas, alebo Hudobný kolektív - ide o takzvaný umelecký plat. Festivaly zvyknú tiež objednávat’ nové diela. Pamätám si, že ked' som tu začínal, tak bolo vel'mi t’ažké získat' čo i len informácie o tom, čo je k dispozícii. Dnes je už na stránke Islandského hudobného centra zoznam grantov a výziev, o ktoré môžu skladatelia požiadat'. Nikdy však nejde o nejaké vel'ké peniaze. Zároveň chcem povedat', že najmä v týchto časoch vel'mi cítit’ potrebu pomoci zo štátu, pretože posledných 18 mesiacov bolo mimoriadne zlých. Hudobníci a iní výkonní umelci sú v súčasnosti na Islande úplne bez prostriedkov. Nedostali žiadnu finančnú pomoc, vláda sústred'uje svoje úsilie inde... Povedzme to takto: umenie je obzvlášt’ nízko na ich zozname. Snažíme sa presadit’ nejaké zmeny, ale na jeseň nás čakajú vol'by, v rámci ktorých by mohli zazniet’ všakovaké sl'uby. Nevieme, čo sa stane, ale dúfame, že sa podarí presadit’ nejakú pomoc pre hudobníkov, ktorí už 18 mesiacov nemajú žiadnu prácu. A to ide ako o popovú, tak aj o klasickú scénu. To vôbec nie je dobrá správa!

\section{O. V.: Si tiež mimoriadne aktívny na poli hudobnej edukácie. Aký je na Islande status quo hudobného vzdelávania a aké sú vyhliadky v tomto smere do budúcnosti?}

O. K.: Áno, učitel'stvo je tu vel'mi dôležitou súčast’ou života hudobníkov. Teda, ak chceš prežit'... Nemôžeš prežit’ iba komponovaním alebo hraním hudby. Väčšina z nás teda učí a áno, ludia bývajú mierne prekvapení, ked'zistia, že na Islande je viac 
ako 60 hudobných škôl. Pripomeniem, že Island je malá krajina s necelými 400000 obyvatel'mi. Hudobné školy sú po celej krajine. Viac-menej v každej malej dedine je hudobná škola, ktorá je čiastočne financovaná obcou a čiastočne štátom. Štúdium tu síce zadarmo nie je, žiaci si za hodiny musia platit', ale školné nie je príliš drahé, takže príležitost' tu dostane každý. Naše hudobné školstvo je v skutočnosti oným hnacím motorom toho, že v operných domoch po celej Európe a Amerike vystupujú islandskí hudobníci. Existujú aj iné príklady, napríklad Sigur Rós či Björk. Všetci títo umelci prešli systémom nášho hudobného školstva. Preto rád hovorím, že na tom máme nejaký ten malý podiel. Aj Hildur Guðnadóttir, ktorá vyhrala Oscary, Bafty či Grammy, prešla naším hudobným systémom. Dúfajme teda, že si naše úrady uvedomia, aký je systém hudobného školstva dôležitý! Môže to stát trochu investícií, ale dostaneme ich naspät vd'aka medzinárodnej reputácii, ktorú naši umelci Islandu prinášajú. A čo to znamená pre ekonomiku? V skutočnosti to konkuruje rybolovu. Luudia sú vždy prekvapení tým, aké príjmy poskytuje islandská hudba našej krajine! A to všetko sa začína už v hudobnej škole v malej dedine, kde všetci obyvatelia lovia ryby... I tamojšie deti chodievajú do hudobnej školy, a ktovie, čo budú v budúcnosti robit'. Dúfajme teda, že to takto pôjde i nad’alej a že si zodpovední uvedomia, aká dôležitá je pre nás hudba. Nielen pre deti, ale pre celú krajinu. Preto máme taký prosperujúci symfonický a komorný orchester, ako aj vel’a prosperujúcich komorných zoskupení. Jeden z našich barytonistov dnes spieva v Bayreuthe a d’alších spevákov máme v Metropolitnej opere. A to všetko boli kedysi malé deti študujúce hudbu niekde uprostred ničoho, u ktorých vzdelávanie prebudilo záujem o hudbu. Dúfajme, že to takto pôjde aj nad'alej.

\section{O. V.: Presuňme sa teraz k tvojim kompozičným aktivitám. Ako skladatel' si auto- didakt a na konte máš už niekol'ko stoviek kompozícií. Aká bola tvoja cesta od or- chestrálneho hráča na violončele k aktivitám hudobného skladatel'a? Oslobodzuje skutočnost', že si skladatel' samouk, nejakým spôsobom tvoju hudbu?}

O. K.: Zaujímavá otázka! Opät’, samouk je na Islande „špinavé slovo“, podobne ako amatér. Nepáči sa im, sú voči nemu dost’ podozrievaví. Musíš mat’ titul, aspoň magisterský, ale najlepšie je, ked' máš doktorát. Pritom - aj Elgar bol samoukom. Takisto množstvo iných skladatel'ov bolo v histórii hudby samoukmi. Ak hovoríme o štúdiu kompozície, o čom je vlastne reč? Hovoríme o striktnom palestrinovskom kontrapunkte alebo o zručnosti skomponovat’ fúgu? Či o podobných veciach, ktoré v súčasnosti už nie sú v hudbe úplne relevantné? Áno, je dobré o nich vediet', ale dnes máme to, čo sa nazýva Google. Vd'aka internetu môžeme študovat' hudbu iných ludí, a to aj bez toho, aby sme chodili na univerzitu. Viem, že vela ludí bude z týchto slov prinajmenšom nešt’astných. Povedia si: „Samozrejme, že musíš študovat', inak nevieš, čo robíš..." Pripomeniem ale aj druhú stranu mince - to, že musíš robit vlastné chyby, musíš veci sám vyskúšat', musíš počúvat' a zaujímat' sa o to, čo robia iní skladatelia a ako pracujú. Takým spôsobom sa dokážeš naučit’ strašne vela aj bez toho, aby si musel nutne absolvovat' skúšky. Samozrejme, i ja som bol na akadémii a vyštudoval som hru na violončele. Urobil som to, čo som potreboval, aby som získal diplom a aby som získal prácu. Nikdy som si ale nemyslel, že mojou primárnou prácou bude kariéra violončelistu. To, čo som chcel robit', a to už od úplného začiatku, bolo písat’ a uvádzat' vlastnú hudbu. Violončelo bolo 
vlastne spôsobom, ktorým som sa dostal do hudobného sveta - pomohlo a poslúžilo svojmu účelu. Dnes mám to štastie, že hudba, ktorú píšem, sa lud’om páči. Uvádza sa a často ma žiadajú o nové skladby. $V$ takej malej spoločnosti, akou je Island, je toto vel'mi vzácne. Všetci tu chodia na rovnakú školu, poznajú rovnakých učitelov a chodia na rovnaké univerzity v zahraničí. Takže viac-menej poznajú všetkých v systéme. Ked' potom prídeš ako outsider a nikto nevie, čo si už dokázal, a zároveň sa dozvie, že nie si vyštudovaný, tak začnú byt' k tebe podozrievaví. Odrazu len počúvaš: „Och, obávam sa, že vám teraz nemôžeme nič ponúknut." "Tým sa to stáva o niečo t’ažším. V skutočnosti to však znamená len to, že musíš na sebe tvrdšie pracovat', robit' si svoju prácu a etablovat' sa. Dúfat', že to zvládneš rovnako dobre ako ktokolvek iný, aj ked' si neprešiel oným štvorročným akademickým mlynom, kde si sa učil, ako napísat’ stupnicu C dur. To je však len môj vlastný pohlad. Som si istý, že vela ludí z týchto slov znervóznelo, takže by sme mali azda zmenit tému...

\section{O. V.: Čo stojí na začiatku tvojej novej kompozície? Ktoré aspekty, resp. hudobné kvality sú pre teba dôležité v tvojej hudbe?}

O. K.: Ďalšia dobrá otázka! Myslím si, že každý jeden umelec sa snaží niečo povedat'. Niečo úprimné, niečo, $v$ čo verí. Niečo, čo má zmysel a možno vedie $k$ niečomu alebo niekomu d'alšiemu. Ja musím neustále komponovat', neznášam, ked' mám prázdny pracovný stôl. Ked' začínam pracovat' na novej kompozícii, tak si jednoducho sadnem, som vel'mi potichu a snažím sa predstavit' si, že som na koncerte. Neviem, čo budem počut', len sa pozerám na to pomyselné pódium. Okolo je tma, pódium je osvetlené a v tej chvíli sa snažím zistit', ktoré nástroje sú na pódiu, čo sa deje, čo počujem... Hlasy okolo mňa zrazu utíchnu a ja počujem klarinet alebo violončelo a možno i perkusie. Postupne tak začínam mat' predstavu o onej zvukovej scéne, ktorú chcem vytvorit', ako aj o jej nálade. Odrazu sa pristihnem, ako píšem hudbu. Neviem, odkial' prichádza, neviem, kam smeruje, ale viem, že to, čo počujem, existuje - lebo to vidím pred sebou a mojou jedinou úlohou je zapísat' to. Viem, znie to zvláštne... V skutočnosti len idem tam, kam ma hudba sama zavedie! A to i napriek tomu, že i ja pracujem do určitej miery „podla plánu“. Ked' to však príliš preplánuješ, tak stratíš onú spontánnost', prídeš o ten pocit slobody. Môžeš sa sústredit' na formu, ale môžeš sa od nej aj odtrhnút. Forma ma zaujíma rovnako, ako ma zaujíma to, ako sa z nej vymanit'. Zároveň aj baroková hudba má na mňa vel'ký vplyv. Stáva sa mi často, že sa potom, ako komponujem celé hodiny nejakú skladbu, zastavím, a pritom neviem, kde som posledné tri hodiny „bol“. Odrazu je predo mnou popísaný notový papier. Samozrejme, následne sa musím k tomu vrátit a urobit tú tvrdú prácu. Ale je to tak, ako hovorím, ten počiatočný moment je niekedy celkom zvláštny...

O. V.: Zaujíma ma tiež tvoj vztah $\mathrm{k}$ islandskému jazyku, ktorý si sa musel naučit' takpovediac úplne „od nuly“. Aký je tvoj kompozičný prístup k tomuto jazyku? Preferuješ komponovat' skladby s anglickým či islandským textom?

O. K.: Ak hovoríme o tom, že islandčina je môj druhý jazyk, tak musím povedat', že sa v nej cítim „ako doma“. Pamätám si síce jednu príhodu z čias, ked' bola uvedená jedna z mojich raných piesní. Istý kritik vtedy napísal do novín, že by som sa mal lepšie 
pozriet’ na prízvuky v islandských slovách. A pritom je islandčina, z tohto pohl'adu, vel'mi jednoduchá - prízvuk je vždy na prvej slabike každého slova. Napriek tomu som si tieto slová vzal k srdcu; dnes som v tomto jazyku už celkom doma a zároveň väčšina mojej vokálnej tvorby je v islandčine. Vlastne sa venujem viac komponovaniu piesní v islandskom jazyku než v angličtine, aj ked'i v nej som už vel’a skomponoval. A samozrejme, mám i chrámovú hudbu, ktorá je bud’ v latinčine, alebo v islandčine. Angličtina mi niekedy pripadá zvláštna a inokedy akoby mi zvuky v anglickom jazyku doslova nedávali vôbec zmysel. To som však len ja a moja výstrednost'. Verdiho by som, napríklad, ovela radšej počul v taliančine než $v$ anglickom preklade, $v$ ktorom to jednoducho znie zle. Verdi to napísal v taliančine, takže to musí byt' v taliančine a ak sa to niekto pokúša preložit', neznie to správne. A áno, myslím si, že dnes už ovládam islandčinu ovel'a lepšie, ako ked' som začínal. Prirodzene, trvá nejaký čas, kým sa jazyk takpovediac "usadí". Rád píšem hudbu pre hlas a väčšina mojich skladieb je vlastne vokálnych. Baví ma to, páči sa mi tá zvukovost'. Islandčina je krásny jazyk. Mnohí si myslia, že sa v nej nedá spievat', ale pritom sa dá a znie to krásne!

\section{O. V.: Ktorí skladatelia mali na tvoju tvorbu najväčší vplyv?}

O. K.: Tieto otázky by mal niekto zakázat'! Mení sa to totiž zo dňa na deň, a navyše, dnes už máme všetci tak vel'mi eklektický vkus! Mohol by som povedat', že je to Bach alebo Beethoven či Brahms, alebo ktokolvek iný. Ale nie je to tak! Vplyvní skladatelia - to môže byt' ktokolvek. Azda by niekto iný mohol povedat', že toto znie trochu ako Britten a tamto zas ako Bartók. Ja neviem... Nemôžem ukázat' na niektorý môj takt a povedat', kto ho ovplyvnil. Možno by to mohli urobit' iní l'udia. Tí by mohli upozornit’ na nejaký vplyv, o ktorom by som ja len následne vedel povedat', či je pravdepodobné, že sa nachádza niekde v mojom podvedomí. Dnes v 21. storočí už počúvame strašné množstvo hudby a v tom je ten rozdiel! Ked' si žil v Mozartovej dobe, tak si počul len to, čo vo vedlajšej miestnosti hral iný žijúci človek. Staršiu hudbu si takmer vôbec nepočul, znelo len to, čo sa vtedy aj napísalo. V dnešnej dobe sme však už vystavení úplne všade tol'kej hudbe, že kto vie, odkial' pochádzajú všetky naše vplyvy... Vsiaknu do nás ako do špongie, možno je tam i kúsok Wagnera... Kto vie? Ty mi povedz!

\section{O. V.: Ťažiac z tvojej predchádzajúcej a dost' zaujímavej odpovede by som sa rád opý- tal trošku inak: hudbe ktorých súčasných skladatel'ov v poslednej dobre rád načúvaš?}

O. K.: Toto nie je spravodlivé!!! Súčasní skladatelia? ...kde mám začat??! James McMillan ku mne prehovára. Jeho hudba mi príde vel'mi osobná a hovorí priamočiaro. A je vel'mi zaujímavé počúvat' aj hudbu Arva Pärta. Aj hudbu Alfreda Schittkeho..., ak ho ešte môžeme nazvat' súčasným skladatel'om, na to je už asi dost' dlho mŕtvy. Hmm, súčasných skladatelov je strašne vela, aj na Islande. Nedokážem to takto zhrnút', lebo sa to líši zo dňa na deň. A asi je už očividné, že sa snažím dost’ neobratne vyhnút' tvojej otázke, na ktorú nemôžem dat' definitívnu odpoved'. Je to podobné ako impresionistický obraz, v ktorom vždy uvidíš niečo iné. Aj v každej jednej skladbe, pri každom jednom skladatel'ovi a pri každom jednom zážitku z počúvania objavíš niečo, čo si ešte predtým nepočul. A to sa opät' zmení, už zajtra! Takže mi moju vyhýbavost' budeš musiet’ odpustit'. 


\section{O. V.: Zmenila prebiehajúca pandémia tvoj pohl’ad na význam, resp. účel hudby v našich životoch?}

O. K.: Ondrej, ved’ to dobre poznáš. Ako interpret tráviš väčšinu času sám v miestnosti s gitarou, snažíš sa cvičit' a pracovat'. A ked' ta k tomu prinútia vonkajšie vplyvy, tak si odrazu uvedomíš, že sa vlastne nič nezmenilo. Pandémia samozrejme zasiahla celý náš život a pravdepodobne ešte nejaký čas ho bude ovplyvňovat'. V tomto ohlade si ale myslím, že mám dost' štastie. Celkom rád totiž sedím, premýšlam a píšem hudbu. Uspokojuje ma to. Samozrejme, to, že som bol doma izolovaný bez možnosti vyjst' von a osobne vyučovat’ svojich študentov, ma prinútilo trochu viac premýšlat’ o tom, čo tu na svete robím. Na druhej strane mi to aj mierne zvláštnym spôsobom pomohlo, lebo minulý rok som napísal vel'a hudby. A tento rok tiež. Asi by som bol v tomto období vel'mi neštastný, ak by som nebol skladatel’om. Vd’aka tejto situácii, ktorá možno pripomína akýsi kláštor, sme ale nútení postavit’ sa veciam čelom a zistit', čo je v našich silách. Myslím si, že práve to je to, čo nás mala táto pandémia naučit'. Dúfajme, že na jej druhej strane budeme lepšími l'ud'mi. Aj ked'človek nikdy nevie, l'udia nemajú v oblube, ked' im niekto hovorí, čo majú robit', a nemajú radi vynútené obmedzenia. Preto môže toto všetko ešte dopadnút kadejako! Dúfam však, že sa začneme pozerat' dovnútra!

for Ondrej Vesely

\section{Thoughts in a Pandemic II}

for Guitar
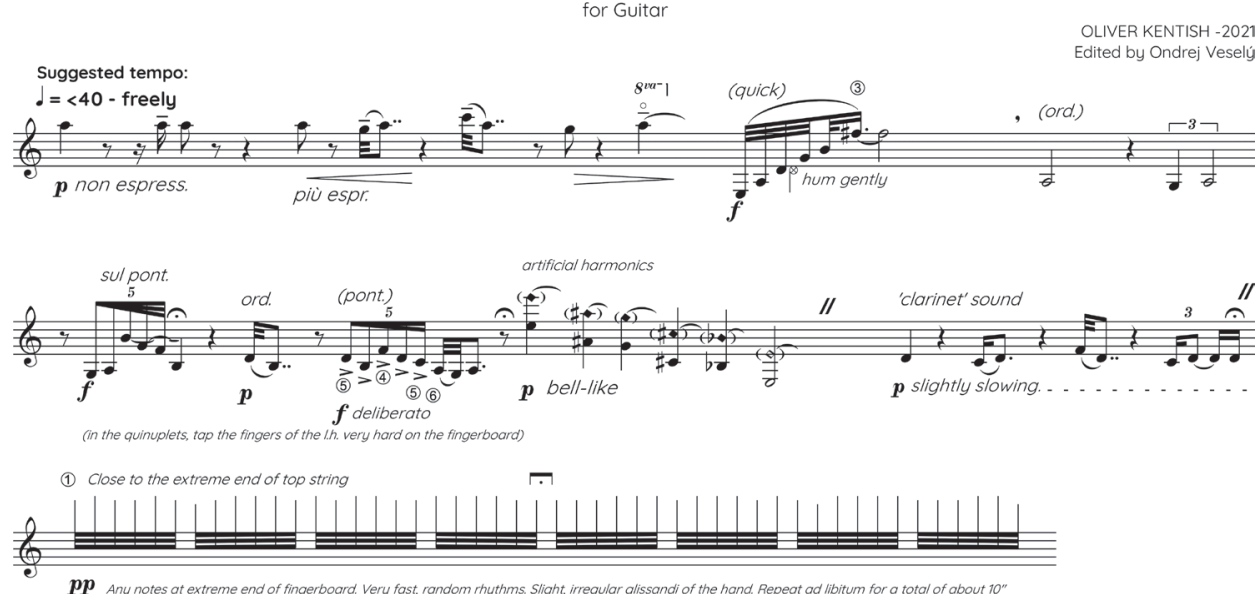

Pp Any notes at extreme end of fingerboard. Very fast, random rhythms. Slight, irregular glissandi of the hand. Repeat ad ibitum for a total of about 10"

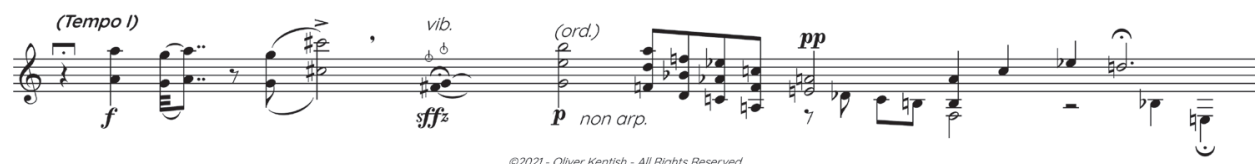

Oliver Kentish sa narodil v Londýne, kde vyštudoval hru na violončele (pod vedením Viviana Josepha) na Královskej hudobnej akadémii. V roku 1977 prišiel na Island a začal hrat’ v Islandskom symfonickom orchestri. V rokoch 1978 - 1986 vyučoval na Akureyri Music School a v súčasnosti vyučuje na Nyja Tónlistarskólinn v Reykjavíku. Pôsobí aj ako zborový a orchestrálny dirigent. Oliver Kentish skomponoval hudbu vo väčšine žánrov, vrátane vel'kého množstva piesní, zborových diel a komornej hudby. V roku 1993 bol poverený britskou vládou, aby skomponoval dielo, ktoré bude darom britského národa obyvatel'om Islandu pri príležitosti pätdesiatich rokov nezávislosti 
Islandu. Dielo My People (v islandčine Mitt fólk) pre barytón a orchester, venované vtedajšej islandskej prezidentke Vigdís Finnbogadóttir, malo premiéru v septembri 1994 v podaní Islandského symfonického orchestra a barytonistu Michaela Clarka pod vedením dirigenta Osmo Vänskä. Oliver získal za svoju hudbu niekolko ocenení a bol trikrát rezidenčným skladatel’om v cykle Skálholt Summer Music, ako aj poberatel'om štipendií od Skladatel'ského fondu Islandského rozhlasu a od Islandského ministerstva umenia a vied. Kentishova hudba sa pravidelne uvádza v Islandskom rozhlase a objavila sa tiež na niekol'kých CD v Európe, škandinávskych krajinách, USA a Rusku (http://shop.mic.is/OriginatorDetail/57728).

\section{John E. Zammitpace}

St. Paul's Bay, Malta, 16. august 2021

O. V.: John, prezrad' niečo o svojom detstve, ako aj o tom, aké bolo vyrastat' na Malte a aké boli tvoje prvé kontakty s hudbou!

J. E. Z.: Narodil som sa v júli 1953 na Malte, v malej krajine, kde bolo ešte stále cítit' negatívne dôsledky 2. svetovej vojny. Naštastie, ked' som mal 8 rokov, začali sme sa na základnej škole učit’ základy hudby, ako napríklad hru na zobcovej flaute, spievali sme v zbore a učili sa základy hudobnej teórie. V mojich 14 rokoch som začal dvakrát alebo trikrát za týždeň navštevovat' hodiny gitary, čo mi poskytlo dobré znalosti o gitare, pope, rocku a klasike.

O. V.: Presuňme sa k tvojim kompozičným aktivitám. Si mimoriadne plodným autorom - na konte máš symfónie, koncertantné diela, sláčikové kvartetá a nemalý počet komorných diel. Ako by si definoval svoju hudbu z pohladu kompozičných techník, estetiky a kompozičných modelov?

J. E. Z.: Napriek tomu, že som mal základy hudobnej teórie, väčšina mojich skladieb vychádza zo skutočnosti, že som autodidakt. Na tom je založená moja sloboda prejavu, a to aj pri používaní zvuku či farieb niektorých nástrojov, či dokonca aj pri obsadení tradičného orchestrálneho aparátu. Do vel'kej miery to ovplyvňuje aj pocit, že moje kompozície sú výsledkom určitej improvizácie zapísanej na papieri. Nie je to však tak! Na svojich skladbách pracujem mesiace, niekedy aj viac než rok, ale vždy sa snažím vzbudit’ dojem, že moja hudba je výsledkom akéhosi toku, resp. rozvíjania témy. Moje kompozičné modely boli zväčša kombináciou klasickej hudby 20. storočia, filmovej hudby a súčasnej, avantgardnej, niekedy dokonca jazzovej hudby.

\section{O. V.: Čo stojí na začiatku tvojej novej kompozície? Ktoré aspekty, resp. hudobné kvality sú pre teba dôležité v tvojej hudbe?}

J. E. Z.: Tok! Niečo, čo je vždy v pohybe a nikdy nie je statické. Bol som a stále som proti opakovaniu motívov a ich prostému zafarbovaniu rôznymi timbrami alebo orchestrálnymi skupinami - povedzme, napríklad, presúvaním sa od sláčikových k dychovým nástrojom a podobne. Radšej pracujem od jedného motívu k druhému, chcem, aby kompozícia znela „akoby sa niečo vznášalo nad akýmsi vel'kým hudobným povrchom a zachytávalo hudobné obrázky, ktoré sa tiež vznášajú" - hovorím metaforicky. 

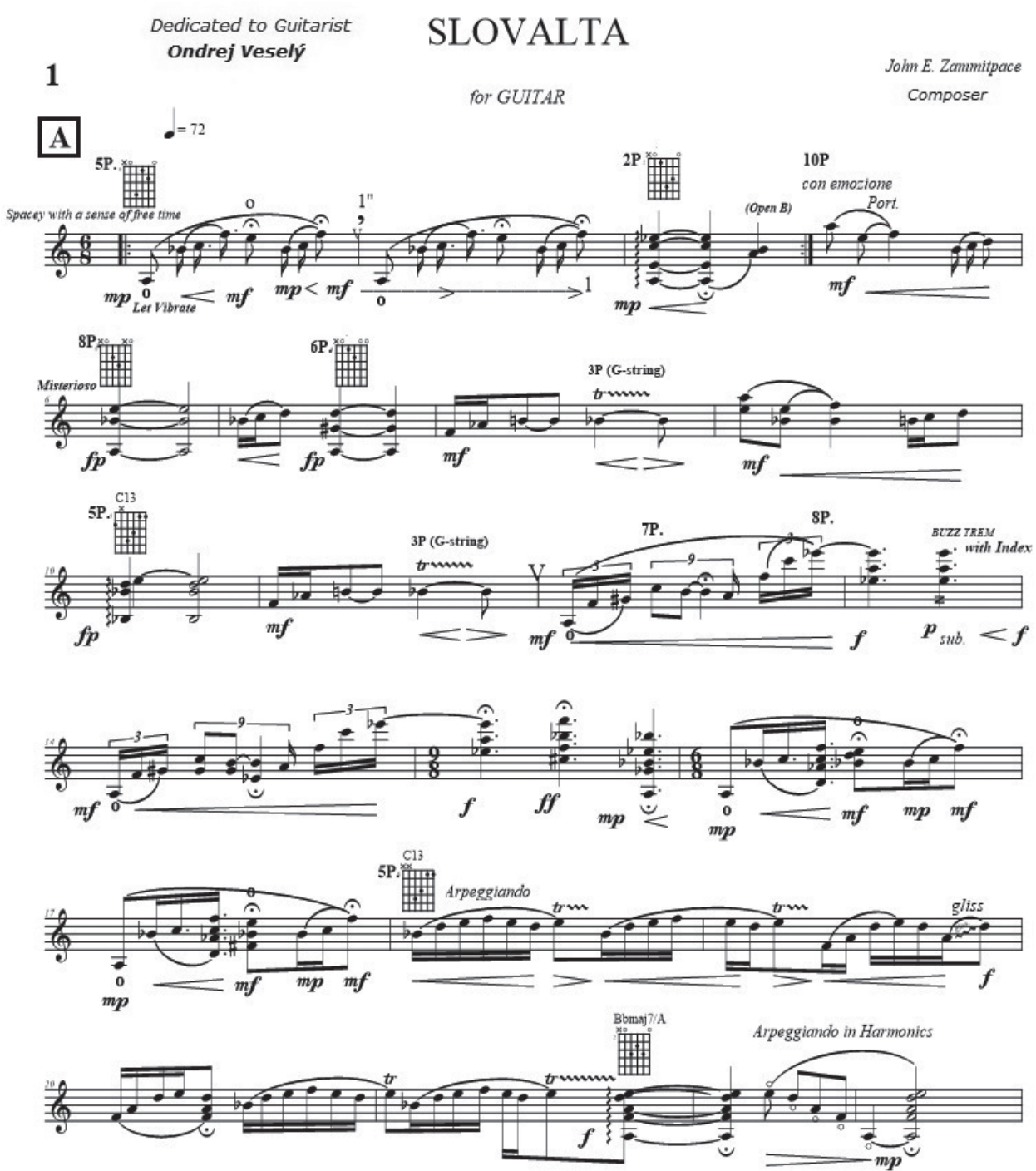

10P
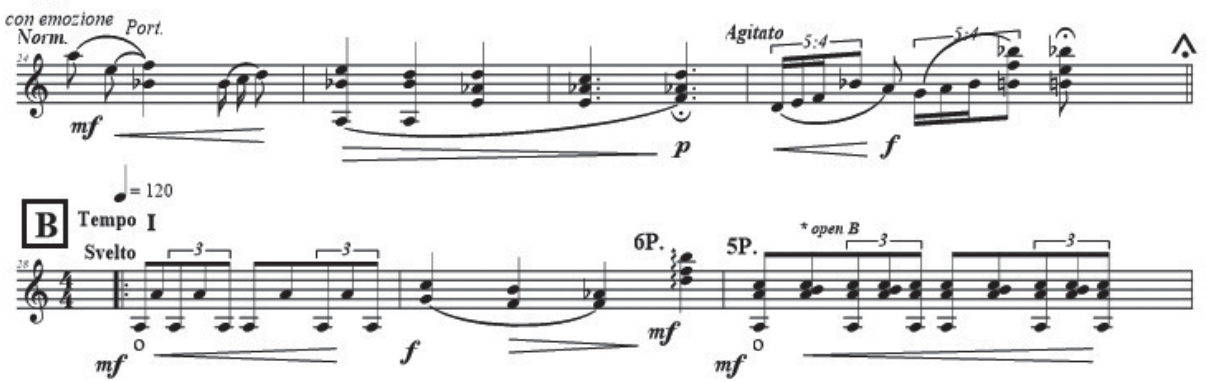

(c) John E. Zammitpace - 2021 


\section{O. V.: Ktorí skladatelia mali na tvoju hudbu najväčší vplyv?}

J. E. Z.: Najvplyvnejšími skladatel'mi boli pre mňa skladatelia filmovej hudby, ako napríklad Lalo Schifrin, Henry Mancini a Ennio Morricone. Do určitej miery ma ovplyvnil aj maltský skladatel' Charles Camilleri, s ktorým som približne pred 30 rokmi spolupracoval na tvorbe partov z jeho opery Compostela. Vtedy som bol ešte študentom Univerzity hudobných štúdií. Neskôr ma ovplyvnili aj klasickí skladatelia 20. storočia, napríklad Mahler, Stravinskij, Schönberg, Berg a Webern a avantgardisti ako Stockhausen, Boulez, Cage, Ferneyhough, Penderecki a vel'a d’alších.

\section{O. V.: Aké sú tvoje kompozičné plány do najbližšej budúcnosti? Na čom pracuješ?}

V súčasnej dobe skladám krátke skladby pre klavír, ako aj znelky a sprievodnú hudbu k rozprávkam. Ale zatial' som vlastne bez príjmu. Dúfam však, že ak sa veci pohnú pozitívnym a zdravým smerom, tak budem pokračovat’ v d’alšej práci pre gitaru a ansámbel.

John E. Zammitpace je skladatel'om klasickej a avantgardnej hudby z Malty. Je autorom približne 150 skladieb, prevažne v notovanom, ale aj grafickom spracovaní. Jeho grafické orchestrálne dielo s názvom Trisolar bolo uvedené v USA v podaní The Chicago Modern Orchestra pod taktovkou skladatel'ky Renee Bakerovej. Zammitpace je autorom symfónií, sláčikových kvartet a koncertov, ale aj niekol'kých komorných skladieb, duet a sólových skladieb pre rôzne nástroje. Počas štúdií ho výrazne ovplyvnila hudba Xenakisa, Stockhausena, Cagea a Bouleza (https:// johnezammitpace.musicaneo.com/about.html).

\section{POZNÁMKY}

$1 \quad$ Webstránka projektu: $h t t p s: / / w w w . o n d r e j-$ vesely.net/reconnect

2 Grant i-Portunus je dotovaný organizáciou Creative Europe Programme of the European 3 Ako hlinené „dosky“ označuje Suilamo šelakové platne, ktoré sa používali približne od konca 19. až do polovice 20. storočia.

Union spoločne s Institut français, Goethe-Institut a Izolyatsia. 